\title{
MAGEA2 wt Allele
}

National Cancer Institute

\section{Source}

National Cancer Institute. MAGEA2 wt Allele. NCI Thesaurus. Code C104500.

Human MAGEA2 wild-type allele is located in the vicinity of Xq28 and is approximately 4 $\mathrm{kb}$ in length. This allele, which encodes melanoma-associated antigen 2 protein, is involved in the regulation of p53-dependent signal transduction. 